(Incorporated editors' comments)

$4^{\text {th }}$ November, 2015

\title{
The Challenge of Non-State Actors: The Experience of the UN Special Rapporteur on the Right to the Highest Attainable Standard of Health (2002-8)
}

\author{
Paul Hunt \\ Professor, Department of Law, Human Rights Centre, University of Essex
}

\section{Introduction}

On one occasion, when I served on the UN Committee on Economic, Social and Cultural Rights (CESCR), the Committee was provided with a substantive report, prepared by a civil society organisation, alleging that a major transnational company was complicit in egregious violations of economic, social and cultural rights in a particular low-income country. The report was submitted to the Committee as part of its periodic review of the country which was a State party to the International Covenant on Economic, Social and Cultural Rights (ICESCR). ${ }^{1}$ Some Committee members took the view that the allegations were so compelling that the Committee should endeavour to engage in a respectful discussion, either written or oral, with the company in question. Other members argued that such an approach would fall beyond the Committee's competence, after all the transnational company had not, and could not, ratify the Covenant; they continued that the Committee should confine itself to asking the State party, during its constructive dialogue, about the government's duty to protect individuals from the depredations of corporate third parties. The latter conventional view prevailed and the Committee declined to engage with the transnational company in question.

Although the wording of their mandates vary, the UN Human Rights Council's Special Procedures tend to have more scope than human rights treaty-bodies, such as CESCR, to consider the acts, omissions and responsibilities of non-state actors. Consider, for example, the mandate establishing the special procedure on the right of everyone to the enjoyment of the highest attainable standard of physical and mental health ('right to health'). It requests the Rapporteur to: 'gather, request, receive and exchange information from all relevant sources'; 'develop a regular dialogue and discuss possible areas of cooperation with all relevant actors, including ... international financial institutions'; 'report on the status of the [right to health] ... and on developments relating to this right, including on laws, policies and good practices most beneficial to its enjoyment and obstacles encountered domestically and internationally to its implementation'; and 'make recommendations on appropriate measures to promote and protect the realization of the [right to health], with a view to supporting States' efforts to enhance public health'. ${ }^{2}$ These provisions, with their references to 'all relevant sources', 'all relevant actors', 'good practices', 'appropriate measures' and so on, give scope to the mandate-holder to explore the role of non-state actors. In short, it is easier for the mandate-holder to look closely at nonstate actors than it is for CESCR.

\footnotetext{
${ }^{1}$ International Covenant on Economic, Social and Cultural Rights (adopted 16 December 1966, entered into force 3 January 1976) 993 UNTS 3 (ICESCR).

${ }^{2}$ United Nations Committee on Economic, Social and Cultural Rights 'General Comment 14' (22 April 2000), UN Doc E/CN.4/RES/2002/31.
} 
When I served as Rapporteur on the right to health (2002-8), Ministers of Health and others convincingly argued that among the obstacles to their implementation of health rights were the policies and practices of non-state actors. These views were expressed, for example, in interviews conducted during missions. In these circumstances, I formed the view that, given the wording of my mandate, it would have been a dereliction of duty not to explore the role of nonstate actors. Of course, I was alert to the possibility that governments might point to non-state actors as a way of excusing or masking their own shortcomings. Throughout the mandate, my primary focus was States and my main task was to hold them accountable. Nonetheless, from time to time, I also considered non-state actors.

This chapter does not aim to examine the substance of my right-to-health reports on non-state actors, such as the World Trade Organisation (WTO), World Bank, International Monetary Fund (IMF), and GlaxoSmithKline (GSK) - this has already been done in a number of different publications. ${ }^{3}$ For the first time, however, the chapter brings together in one place, and reflects upon, several of my more significant experiences with non-state actors while I was Special Rapporteur.

Before proceeding, I would like to signal some important doctrinal matters. I agree with Michael Freeman's observation that 'the concept of human rights is centrally concerned with the misuse of power'. In its statement on poverty in 2001, CESCR takes a similar position: 'Although human rights are not a panacea, they can help to equalize the distribution and exercise of power within and between societies. ${ }^{5}$ However, the contemporary concept of international human rights is more narrowly drawn: its focus is neither power, nor even public power, in general. The contemporary concept of international human rights is intended 'primarily to protect individuals from the abuse of power by governments' ${ }^{6}$ This preoccupation with individuals as rights-holders and governments as duty-bearers reflects the main concerns of the architects of the International Bill of Rights in the shadow of the Second World War. Many of them had witnessed the persecution of individuals by deeply oppressive State power. Understandably, they toiled to negotiate an international code of conduct that would protect individuals from abusive States. In my view, however, there is no compelling reason why the concept of human rights cannot

\footnotetext{
${ }^{3}$ See eg P Hunt and S Leader, 'Developing and applying the right to the highest attainable standard of health: the role of the UN Special Rapporteur' in J Harrington and M Stuttaford (eds), Global Health and Human Rights: Philosophical and Legal Perspectives ((Routledge 2010); P Hunt and S Walker, 'WTO member states and the right to health' in J Dine and A Fagan (eds), Human Rights and Capitalism (Edward Elgar Publishing 2006); P Hunt, J Mesquita and R Khosla, 'The human rights responsibility of international assistance and cooperation in health' in M Gibney and S Skogly (eds), Universal Human Rights and Extraterritorial Obligations (Pennsylvania Studies in Human Rights 2010); J-Y Lee and P Hunt, 'Human rights responsibilities of pharmaceutical companies in relation to access to medicines' (2012) Journal of Law, Medicine and Ethics 220; P Hunt and R Khosla, 'Holding pharmaceutical companies to account: a UN Special Rapporteur's mission to GlaxoSmithKline' in G Gilbert, F Hampson and C Sandoval (eds), The Delivery of Human Rights: Essays in Honour of Professor Sir Nigel Rodley (Routledge 2010); P Hunt and R Khosla, 'The human right to medicines' (2008) Sur: International Journal on Human Rights 98.

${ }^{4}$ Emphasis in original. M Freeman, Human Rights (2 ${ }^{\text {nd }}$ edn, Polity Press 2011) 210.

${ }^{5}$ UN CESCR 'Substantive Issues Arising in the Implementation of the International Covenant on Economic, Social and Cultural Rights: Poverty and the International Covenant on Economic, Social and Cultural Rights' (10 May 2001), UN Doc E/C.12/2001/10.

${ }^{6}$ Freeman (n 4) 16.
} 
encompass groups of individuals as rights-holders and powerful non-state actors as duty-bearers. Of course, contemporary international human rights are designed to hold States accountable and it would be facile simply to apply these standards to non-state actors. For example, although ICESCR includes an obligation to adopt 'legislative measures', it would be absurd to suggest that transnational corporations should have legislative powers. ${ }^{7}$ Plainly, normative adjustments are needed if human rights obligations are to extend to powerful non-state actors. While it is not the purpose of this chapter to examine the doctrinal dimensions of these issues, in my view the concept of human rights is impoverished if it is confined to the misuse of State power. ${ }^{8}$ We have to find suitable ways -- new thinking and practice -- to extend human rights accountability to powerful non-state actors. This is what animated my exploratory initiatives as briefly outlined in this chapter.

After these introductory remarks, this chapter looks at non-state actors in relation to the three types of reports I submitted to the United Nations. First, I consider two thematic reports on the pharmaceutical sector, including a report submitted to the General Assembly setting out Human Rights Guidelines for Pharmaceutical Companies in relation to Access to Medicines. Second, I discuss 'country' reports which I used as a vehicle for looking at non-state actors, such as the WTO, World Bank, IMF and GSK. Third, I introduce my reports on complaints (or 'communications' to use the language of the United Nations) about alleged violations of the right to health that were brought to my attention when the allegations were unconnected with a country visit; these reports include complaints against two non-state actors. The chapter ends with a brief conclusion.

\section{Thematic reports}

Like other special procedures, when preparing thematic reports, I always consulted with nonstate actors, such as UN agencies and civil society. ${ }^{9}$ Additionally, the thematic reports often considered the roles of non-state actors in relation to the right to health issues that were the subject of the reports. ${ }^{10}$ However, because of the strict word limits placed on these reports, their treatment of non-state actors was often superficial. I formed the view that I could not depend upon these usual methodological approaches when looking at the pharmaceutical sector which plays such a critically important role in relation to one vital component of the right to health: access to medicines. On numerous occasions, ministers, senior public officials, civil society and others complained that the policies of some pharmaceutical companies, including their excessively high prices for medicines, were an obstacle to the national implementation of the

\footnotetext{
${ }^{7}$ International Covenant on Economic, Social and Cultural Rights (adopted 16 December 1966, entered into force 3 January 1976) 993 UNTS 3 (ICESCR), Art 2(1).

${ }^{8}$ Among the relevant literature is A Clapham, Human Rights Obligations of Non-State Actors (OUP 2006); N

Rodley, 'Non State Actors and Human Rights' in S Sheeran and N Rodley (eds), Routledge Handbook of International Human Rights Law (Routledge 2013); P Alston, 'The "Not-a-Cat" Syndrome: Can the International Human Rights Regime Accommodate Non-State Actors?', in P Alston (ed), Non-State Actors and Human Rights (OUP 2005).

${ }^{9}$ See, for example, UN Commission on Human Rights (UNCHR) 'The right of everyone to the enjoyment of the highest attainable standard of physical and mental health: Report of the Special Rapporteur, Paul Hunt' (13 February 2003) UN Doc E/CN.4/2003/58, paragraphs 3-7.

${ }^{10}$ See, for example, UNCHR 'Report of the Special Rapporteur on the right of everyone to the enjoyment of the highest attainable standard of physical and mental health, Paul Hunt' (11 February 2005) UN Doc E/CN.4/2005/51, paragraph 49.
} 
right to health. Accordingly, I devised three ways of addressing the human rights responsibilities of pharmaceutical companies: first, in a thematic report on access to medicines that includes sections on the responsibilities of States and pharmaceutical companies; ${ }^{11}$ second, in a thematic report that presented Human Rights Guidelines for Pharmaceutical Companies in relation to Access to Medicines to the General Assembly; ${ }^{12}$ and third, in a formal mission to GSK. ${ }^{13}$ I briefly comment on the two thematic reports in this section and introduce the GSK report in the next.

My thematic report to the General Assembly in 2006 underlined that there is a human right to medicines and explored its different dimensions, such as access, quality, participation and accountability. ${ }^{14}$ It emphasised that states have primary responsibility to increase access to medicines but underscored that Millennium Development Goal 8 confirms this is a shared responsibility and pharmaceutical companies are among those with some responsibility. ${ }^{15}$ The report argued that a consensus is emerging that business enterprises have some legal and ethical human rights responsibilities and it introduces draft Guidelines on the scope and content of the responsibilities of pharmaceutical companies in relation to access to medicines. ${ }^{16}$ The report encouraged all parties to submit comments on the draft Guidelines. ${ }^{17}$

My last report to the General Assembly in 2008 presented the finalised Human Rights Guidelines for Pharmaceutical Companies in relation to Access to Medicines, which consist of a preamble, 47 guidelines and a commentary. ${ }^{18}$ The Guidelines are detailed, specific and practical. They address a wide range of issues including transparency, corruption, lobbying, clinical trials, patents, licensing, pricing and accountability. The report explains the lengthy consultative process from which the Guidelines emerged. ${ }^{19}$ I will not set out this process here but note three features of it. First, stretching over some five years, the process included many discussions and workshops with the pharmaceutical sector. Second, civil society played a very significant part. Third, for much of this process, leadership was provided by former High Commissioner for Human Rights, Mary Robinson, President of Realizing Rights: The Ethical Globalization Initiative (EGI). The contributions of Mary Robinson and her EGI colleagues were indispensable.

The effective promotion and protection of human rights requires a keen sense of strategy. In the context under discussion, I made a strategic calculation which requires brief explanation. As reported to the General Assembly in 2006, the key issues in relation to the pharmaceutical sector

\footnotetext{
${ }^{11}$ UN General Assembly (UNGA) 'Report of the Special Rapporteur on the right of everyone to the enjoyment of the highest attainable standard of physical and mental health, Paul Hunt' (13 September 2006) UN Doc A/61/338.

${ }^{12}$ UNGA 'Report of the Special Rapporteur on the right of everyone to the enjoyment of the highest attainable standard of physical and mental health, Paul Hunt' (11 August 2008) UN Doc A/63/263.

${ }^{13}$ UNGA 'Report of the Special Rapporteur on the right of everyone to the enjoyment of the highest attainable standard of physical and mental health, Paul Hunt - Mission to GlaxoSmithKline' (5 May 2009) UN Doc

A/HRC/11/12/Add.2.

${ }^{14}$ UNGA (n 11).

${ }^{15}$ ibid, paragraph 82 .

${ }^{16}$ ibid, paragraphs 90 and 92 .

17 ibid, paragraph 91.

${ }^{18}$ UNGA (n 12) section IV and annex.

19 ibid, section IV.
} 
and human rights include, first, clarifying the scope and content of the sector's human rights responsibilities, and second, identifying which are legal and which are ethical responsibilities. ${ }^{20}$ In my view, discussion within the human rights community usually focussed on the second issue and neglected the first, and this led to a complaint from some pharmaceutical companies that, while they were willing to comply with the right to health, nobody could explain to them the contours and content of their right to health responsibilities. Thus, I made a strategic decision temporarily to put aside the second issue and to focus on the first.

Accordingly, as reported to the General Assembly in 2008, Mary Robinson and I proposed a collaborative project with some pharmaceutical companies with a view to identifying the right to health responsibilities of the pharmaceutical sector; regrettably, the companies' response to our proposal was insufficient for the project to proceed. ${ }^{21}$ Undaunted, I prepared Guidelines that demonstrate, in some detail, how international human rights norms apply to pharmaceutical companies in relation to access to medicines. Importantly, my focus on clarifying the scope and content of pharmaceutical companies' human rights responsibilities, rather than identifying which are legal and which are ethical, should not be interpreted as meaning that, in my view, international human rights norms place no legally binding obligations on pharmaceutical companies. On the contrary, as I emphasise in the 2006 report, 'it is inconceivable that some human rights do not place legal responsibilities on business enterprises' ${ }^{22}$ Identifying which responsibilities of pharmaceutical companies in relation to access to medicines are legal, and which are ethical, is an important but different exercise.

\section{3. 'Country' reports}

My first report to the UN Commission on Human Rights in 2003 identified my priorities as mandate-holder, one of which was to consider the WTO. ${ }^{23}$ I thought it would send a suitable message if my first 'country' report was on WTO. Conscious this would be the first of its kind, I informally discussed the idea with the High Commissioner for Human Rights, Sergio de Mello. While leaving the decision to me, the High Commissioner encouraged me to proceed. After I had decided to go ahead, it was agreed that the High Commissioner would take the unusual step of writing to the Director-General of WTO, Supachai Panitchpakdi, proposing that I visit. ${ }^{24}$ The Director-General replied positively and, in due course, an intense seven-day schedule of meetings with WTO members, WTO secretariat and many others, took place. ${ }^{25}$ One of the mission's aims was to highlight the problem of disconnected government, ie one part of government (trade) does not necessarily grasp what another part of the same government (justice and foreign affairs) has agreed to do. The mission also sought to highlight disconnect between international bodies, for example, WTO and OHCHR. Thus, the mission alerted the WTO secretariat to the health rights dimensions of their work. Published in 2004, the mission report addressed these, and a range of complex trade issues, through a right to health 'lens'. ${ }^{26}$

\footnotetext{
${ }^{20}$ UNGA (n 11) paragraph 93.

${ }^{21}$ UNGA (n 12), section IV.

${ }^{22}$ UNGA (n 11), para 93.

${ }^{23}$ UNCHR (n 9).

${ }^{24}$ UNCHR 'The right of everyone to the enjoyment of the highest attainable standard of physical and mental health: report of the Special Rapporteur, Paul Hunt - Mission to the World Trade Organization' (1 March 2004) UN Doc E/CN.4/2004/49/Add.1, paragraph 2,

${ }^{25} \mathrm{ibid}$, Introduction.

${ }^{26}$ ibid.
} 
My second report on Sweden looked at analogous issues but this time in relation to the World Bank and IMF. In January 2006, I was invited to Sweden to prepare a report on how the Government was domestically implementing the right to health. ${ }^{27}$ Subsequently, I informed the Government that I was interested in preparing a second report, this time on the implementation of Sweden's international policies so far as they bear upon the right to health. To its credit, the Government agreed to cooperate. This second report was a way of exploring Sweden's extraterritorial human rights obligations, analysing the meaning and application of 'international assistance and cooperation' as set out in article 2(1) ICESCR, and taking health rights into the halls and corridors of the World Bank and IMF. Thus, in October 2006 I visited Washington DC and discussed with the Executive Directors of the Nordic-Baltic countries in the World Bank and IMF (ie, the representatives of Sweden in the Bank and IMF) how they sought to take account of Sweden's international human rights policies in their work. In February 2007, at the invitation of Uganda, I visited Kampala to examine how Sweden, especially the Swedish International Development Cooperation Agency, contributes to the realisation of the right to health in Uganda. I also wished to explore Sweden's role in Zambia's health sector but did not receive Lusaka's permission to visit, accordingly my report does not include Zambia. The report made numerous recommendations for Sweden and its representatives in the World Bank, the IMF and Uganda. Some of the report has general application, such as the section outlining the human rights responsibility of international assistance and cooperation in health. ${ }^{28}$ The points made in this section are not only relevant to Sweden, but all donors, as well as members of the World Bank and IMF. Additionally, the report addressed some of the institutional barriers to the operationalisation of health rights within the Bank and Fund. ${ }^{29}$

Throughout my mandate, I regularly scrutinised States' duties and practice in relation to access to medicines. As already discussed, I began to look closely at the responsibilities of the pharmaceutical sector in relation to access to medicines and devised three ways of advancing this agenda, two of which I have signalled in the preceding section. The third initiative was to conduct a formal mission to GSK. Before proceeding, however, I took two steps. First, given the unprecedented nature of the proposed mission, I informally consulted Gay McDougall, Chair of the Coordination Committee of Special Procedures of the UN Human Rights Council, who indicated that, while it was entirely a matter for me, the mission had her support. Second, pharmaceutical companies and access to medicines raise technical issues and so I hired a consultant, with many years of experience of the pharmaceutical sector, to provide some technical advice. I chose GSK because it is one of the world's leading research-based pharmaceutical companies. GSK confirmed their agreement to the mission and months of research began. Many meetings took place, including with the highest levels of management in GSK's headquarters, as well as civil society organisations working on access to medicines. Effectively, the GSK report drew from, and applied, the Human Rights Guidelines for Pharmaceutical Companies in relation to Access to Medicines.

\footnotetext{
${ }^{27}$ UN Human Rights Council (UNHRC) 'Report of the Special Rapporteur on the right of everyone to the enjoyment of the highest attainable standard of physical and mental health, Paul Hunt - Mission to Sweden' (28 February 2007) UN Doc A/HRC/4/28/Add.2.

${ }^{28}$ UNHRC 'Report of the Special Rapporteur on the right of everyone to the enjoyment of the highest attainable standard of physical and mental health, Paul Hunt - Missions to the World Bank and the International Monetary Fund in Washington, D.C. and Uganda' (5 March 2008) UN Doc A/HRC/7/11/Add.2, Section II.

${ }^{29}$ ibid, section V, B.
} 
From the perspective of the right to health, the report critiques some GSK policies on access to medicines, especially in relation to developing countries, and makes numerous recommendations for GSK, States and others. ${ }^{30}$ The report was formally presented to the UN Human Rights Council in June 2009 by my successor Anand Grover. I tried to ensure that GSK could orally respond to the report from the floor of the Council, just as a State is able to respond to a report on itself. Although GSK wished to speak, and a senior company representative was present in the Council at the relevant time, permission was not granted by the President of the Council. This was regrettable and inconsistent with well-established principles of procedural fairness. However, the President publicly referred to GSK's written response, which was circulated in the Council. The GSK report generated considerable interest. For example, the UK delegate made an oral statement thanking both GSK and the author, and said 'businesses should ... ensure that they conduct their activities in a manner that is consistent with enjoyment of human rights' ${ }^{31}$ In an article headed 'Right-to-health responsibilities of pharmaceutical companies', the Lancet published an editorial on the GSK report and Guidelines: 'Pharmaceutical companies help deliver the right to health. They save lives. But with this role comes responsibilities - and companies must be better held to account in relation to those responsibilities. The 2008 guidelines and the GSK report move us closer to that goal. ${ }^{, 32}$ My focus in this section has been on the missions to the WTO, the World Bank and the IMF, and GSK. However, during more orthodox country-focused missions I also engaged with international financial institutions and pharmaceutical companies. For example, when visiting Mozambique I discussed relevant health rights issues with the World Bank in Maputo, ${ }^{33}$ and when preparing a report on neglected diseases in Uganda I met with local representatives of pharmaceutical companies in Kampala. ${ }^{34}$ Sometimes my interlocutors in these meetings were mystified by my interest and questions. But the main point of engaging with them was to convey that the work of their institutions was intimately connected with international health rights.

\section{Complaints}

Although the right to health mandate does not explicitly include the receipt of complaints, I took up some of the alleged violations that were brought to my attention by individuals and organisations even when the allegations were unconnected with a country visit. Four annual reports summarising these communications were submitted to either the Commission on Human Rights or Human Rights Council. ${ }^{35}$ While the bulk of these complaints were against

\footnotetext{
${ }^{30}$ UNGA (n 13), sections IV and V.

${ }^{31}$ Hunt and Khosla (n 3) 67.

${ }^{32}$ Editorial, 'Right-to-health responsibilities of pharmaceutical companies' (13 June 2009) 373(9680) The Lancet 1998

$<$ http://www.thelancet.com/pdfs/journals/lancet/PIIS0140-6736(09)61090-4.pdf > accessed 22 October 2015.

${ }^{33}$ UNCHR 'The right of everyone to the highest attainable standard of physical and mental health: Report of the Special Rapporteur, Paul Hunt. Addendum - Mission to Mozambique’ (4 january 2005), UN Doc E/CN.4/2005/51/Add.2.

${ }^{34}$ UNCHR 'Report of the Special Rapporteur on the right of everyone to the highest attainable standard of physical and mental health, Paul Hunt: Addendum - Mission to Uganda' (19 January 2006) UN Doc E/CN.4/2006/48/Add.2.

${ }^{35}$ UNCHR 'Report of the Special Rapporteur on the right of everyone to the highest attainable standard of physical and mental health, Paul Hunt: Addendum - Summary of cases transmitted to Governments and replies received' (2 February 2005) UN Doc E/CN.4/2005/51/Add.1; UNCHR 'Report of the Special Rapporteur on the right of everyone to the highest attainable standard of physical and mental health, Paul Hunt: Addendum - Summary of communications sent to and replies received from Governments and other actors, December 2004-December 2005'
} 
governments, communications were also sent to the UN Interim Administration Mission to Kosovo (UNMIK), as well as the Global Fund to Fight AIDS, Tuberculosis and Malaria. In 2005, an urgent appeal to UNMIK, with two other Rapporteurs, concerned the relocation of internally displaced persons affected by severe lead contamination in camps in northern Kosovo; a constructive correspondence continued until 2007. ${ }^{36}$ In 2005, a letter to the Global Fund expressed concern about the Fund's decision to terminate grants to Myanmar and an inconclusive correspondence continued into 2006. ${ }^{37}$ The title of the annual reports on communications changed from Summary of cases transmitted to Governments and replies received (2005) to Summary of communications sent to and replies received from Governments and other actors (2008, emphasis added).

\section{Conclusion}

While States occupied the bulk of my time as mandate holder, exploring the role of non-state actors was a recurrent theme occupying about 10 per cent of my capacity as Rapporteur. Nobody tried to dissuade me from looking at non-state actors. High-income countries tended to be more diffident than low- or middle-income countries. Reaction within the World Bank, IMF and WTO to this dimension of my work was patchy, ranging from enthusiasm to confusion. With regard to pharmaceutical companies, some that I engaged with were very well-informed and constructive; others were going through the motions. Moreover, I always had the sense that my engagement with them was something they wished to control. There was a degree of nervousness among some (not all) OHCHR staff, but they were unfailingly supportive, professional and very hardworking. The support provided by High Commissioner Sergio de Mello, and the collaborative leadership provided by former High Commissioner Mary Robinson was extremely important. On the whole, civil society was enthusiastic, although some worried I would 'sell-out' and others were concerned that I would go too far.

Of course, I never expected the WTO, World Bank and IMF suddenly to mainstream health rights into their work, and I knew it was unlikely that pharmaceutical companies would embrace the Human Rights Guidelines for Pharmaceutical Companies in relation to Access to Medicines. My aims were to expose disconnected government, to signal how health rights mainstreaming could occur in the WTO, World Bank and IMF, to show that it was possible to apply human rights norms - with a considerable degree of operational specificity - to pharmaceutical companies in relation to access to medicines, and to demonstrate that GSK, one of the world's largest pharmaceutical companies, could be held accountable by a UN human rights mechanism.

(22 December 2005) UN Doc E/CN.4/2006/48/Add.1; UNHRC 'Report of the Special Rapporteur on the right of everyone to the highest attainable standard of physical and mental health, Paul Hunt: Addendum - Summary of cases transmitted to Governments and replies received' (23 February 2007) UN Doc A/HRC/4/28/Add.1; UNHRC 'Report of the Special Rapporteur on the right of everyone to the highest attainable standard of physical and mental health, Paul Hunt: Addendum - Summary of communications sent to and replies received from Governments and other actors' (4 March 2008) UN Doc A/HRC/7/11/Add.1.

${ }^{36}$ UNCHR 'Report of the Special Rapporteur on the right of everyone to the highest attainable standard of physical and mental health, Paul Hunt: Addendum - Summary of communications sent to and replies received from Governments and other actors, December 2004-December 2005' (22 December 2005) UN Doc E/CN.4/2006/48/Add.1, paragraphs 78-80; UNHRC 'Report of the Special Rapporteur on the right of everyone to the highest attainable standard of physical and mental health, Paul Hunt: Addendum - Summary of cases transmitted to Governments and replies received' (23 February 2007) UN Doc A/HRC/4/28/Add.1, paragraphs 56-58.

${ }^{37}$ UNCHR (n 36), paragraphs 76-77; UNHRC (n 36), paragraphs 51-55. 
In the Introduction, I observe that international human rights were primarily designed, in the years following the Second World War, to protect individuals from the abuse of power by governments. For this reason, it was more challenging to give serious thought to the possibility of extending human rights accountability to non-state actors, than it was to actually undertake the initiatives outlined in this chapter. In the long term, perhaps the most significant feature of these initiatives is that they took place at all. 